\title{
The Fatality Assessment and Control Evaluation program's role in the prevention of occupational fatalities
}

\author{
D N Higgins, V J Casini, P Bost, W Johnson, R Rautiainen
}

Trauma Investigation Section, Division of Safety Research, National Institute for Occupational Safety and Health, Morgantown, West Virginia

D N Higgins

V J Casini

New Jersey Department of Health and Senior Services, Occupational Health Service, P O Box 360 , Trenton, New Jersey P Bost

Institute for Rural and Environmental Health, University of Iowa, Iowa City, Iowa W Johnson

Great Plains Center for Agricultural

Health, Institute for Rural and

Environmental Health,

University of Iowa,

Iowa City, Iowa

R Rautiainen

Correspondence and reprint requests to: Doloris Higgins, State FACE Project Officer, National Institute for

Occupational Safety and

Health, 1095 Willowdale

Road, M/S H-1812,

Morgantown, WV

26505-2888, USA

dyh4@cdc.gov

\begin{abstract}
Objectives-The objective of the Fatality Assessment and Control Evaluation (FACE) program is to prevent traumatic occupational fatalities in the United States by identifying and investigating work situations at high risk for injury and formulating and disseminating prevention strategies to those who can intervene in the workplace.

Setting-The FACE program is a research program located in the Division of Safety Research, a division of the National Institute for Occupational Safety and Health (NIOSH). NIOSH is an agency of the United States government and is part of the Centers for Disease Control and Prevention. NIOSH is responsible for conducting research and making recommendations for prevention of work related illnesses and injuries. FACE investigators conduct traumatic occupational fatality investigations throughout the United States and provide technical assistance to 15 state health or labor departments who have cooperative agreements with NIOSH to conduct traumatic fatality surveillance, targeted investigations, and prevention activities at the state level.
\end{abstract}

Methods-Investigations are conducted at the worksite using the FACE model, an approach derived from the research conducted by William Haddon Jr. This approach reflects the public health perspective that the etiology of injuries is multifactorial and largely preventable. FACE investigators gather information on multiple factors that may have contributed to traumatic occupational fatalities. Information on factors associated with the agent (energy exchange, for example, thermal energy, mechanical energy, electrical energy, chemical energy), host (worker who died), and the environment (the physical and social aspects of the workplace), during the pre-event, event, and post-event time phases of the fatal incident are collected and analyzed. Organizational, behavioral, and environmental factors contributing to the death are detailed and prevention recommendations formulated and disseminated to help prevent future incidents of a similar nature.

Results-Between 1982 and the present, more than 1500 fatality investigations have been conducted and reports with prevention recommendations distributed. Findings have been published in scientific and trade journals; safety professionals and policy makers have used FACE findings for prevention efforts; and working partnerships have been formed to address newly emerging safety concerns.

Conclusions-FACE investigations identify multiple factors contributing to fatal occupational injuries, which lead to the formulation and dissemination of diverse strategies for preventing deaths of a similar nature.

(Injury Prevention 2001;7(Suppl I):i27-33)

Keywords: occupational fatalities; occupational injury

Overview of the FACE program

Traumatic occupational fatalities represent a public health problem of significant proportion. Based on data from the National Traumatic Occupational Fatalities (NTOF) surveillance system $^{\star}$, more than 94000 occupational injury deaths occurred in the United States for the period 1980-95. ${ }^{1}$ Recent data from the Bureau of Labor Statistics' Census of Fatal Occupational Injuries (CFOI) $†$ documented 6023 work related injury deaths in $1999 .^{2}$

Surveillance data sources such as NTOF and CFOI are useful for setting research and prevention priorities as they identify common causes of death and worker groups which are experiencing large numbers and/or rates of occupational injury death. However, to develop effective prevention measures, more in-depth information is required to understand the circumstances and contributors to fatal injuries. The purpose of this paper is to describe the Fatality Assessment and Control Evaluation (FACE) program and to illustrate methods used to identify fatalities and prevent them through collaborative efforts.

The FACE program is a research program located in the Division of Safety Research, a

${ }^{\star} \mathrm{NTOF}$ is based on death certificates compiled from 52 vital statistics reporting units in the United States. Inclusion criteria include age equal to or greater than 16 years, external cause of death (International Classification of Diseases, 9th Revision codes E800 to E999), and "injury at work" designations.

†CFOI is based on data compiled from various state and federal administrative sources, such as death certificates, worker's compensation reports, Occupational Safety and Health Administration reports, and medical examiner's reports. Data have been collected from all 50 states since 1992 on all work related traumatic injury deaths without age limitations. 


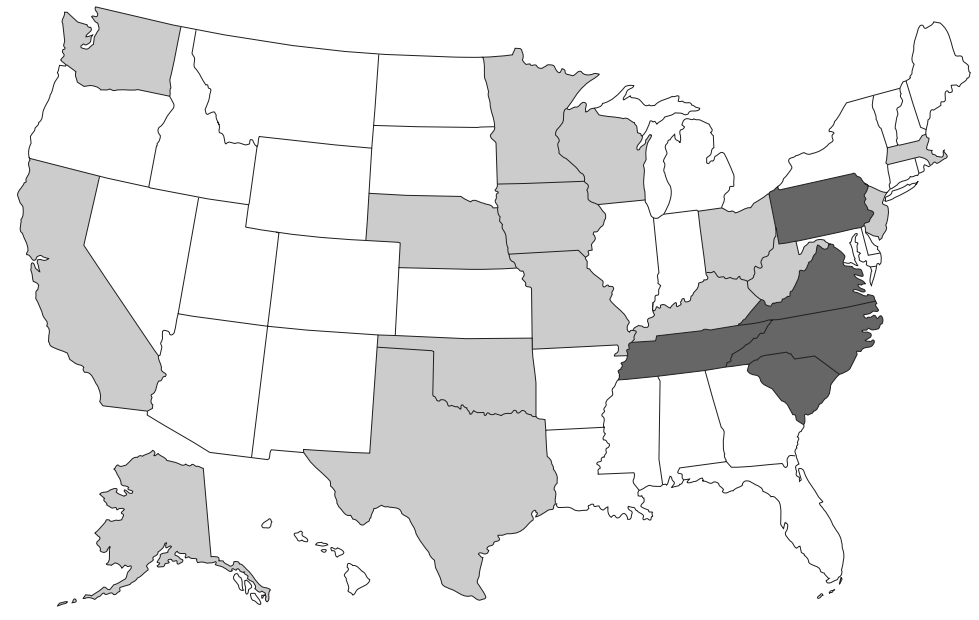

Division of Safety Research FACE states State based FACE states

Figure 1 States participating in the FACE program.

division of the National Institute for Occupational Safety and Health (NIOSH). NIOSH is an agency of the United States government and is part of the Centers for Disease Control and Prevention. NIOSH is responsible for conducting research and making recommendations for prevention of work related illnesses and injuries. The primary goal of the FACE program is to prevent occupational fatalities by identifying industries and workers with high risk for fatal injury, investigating work situations where fatalities occur, and formulating and disseminating prevention strategies to those who can intervene in the workplace. FACE investigators do not determine fault or enforce compliance with state or federal occupational safety and health standards. The United States Department of Labor, Occupational Safety and Health Administration (OSHA) is the federal agency responsible for promulgation and enforcement of occupational safety and health regulations.

The program has two components. The first is the Division of Safety Research based FACE, established in 1982, which conducts investigations of occupational traumatic fatalities from targeted causes in participating states (currently North Carolina, Pennsylvania, South Carolina, Tennessee, and Virginia). Targeted causes of death are determined by NIOSH after reviewing NTOF and CFOI data, reviewing current work related injury and fatality literature, and after consulting with other agencies responsible for worker safety and health. Targets have included confined spaces, electrocutions, falls from elevation, and logging. Current causes of death targeted for investigation include machine related and highway/street work zone construction. Additionally, work related deaths of youths under 18 years of age have been investigated nationwide since 1999 when the United States Department of Labor, Wage and Hour Division, began notifying NIOSH of youth deaths.
The second component of the program is state based FACE, which began in 1989. Currently, health or labor departments from 15 states (Alaska, California, Iowa, Kentucky, Massachusetts, Missouri, Minnesota, Nebraska, New Jersey, Ohio, Oklahoma, Texas, Washington, Wisconsin, and West Virginia) have cooperative agreements with NIOSH for conducting surveillance, targeted investigations, and prevention activities at the state level using the FACE model (see fig 1 for participating FACE states). In addition to investigating deaths targeted by NIOSH, states set their own investigation targets based on analysis of their state's fatal traumatic injury data.

Investigations of work related deaths in both the Division of Safety Research based and state based programs are conducted using the FACE model. This model was derived from research conducted by William Haddon Jr and reflects the public health perspective that the etiology of injuries is multifaceted and largely preventable. ${ }^{3}$ Face investigators collect information on factors associated with the agent (mode of energy exchange, for example, thermal energy, mechanical energy, electrical energy, chemical energy), the host (worker who died), and the environment (the physical and social aspects of workplace) during the pre-event, event, and post-event time phases of the fatal incident through employer and witness interviews, examination of the incident site, and review of multiple source documents such as OSHA, medical examiner, and police reports. FACE investigators develop narrative reports that detail organizational, behavioral, and environmental factors that contributed to the death. Recommendations for prevention are then developed and disseminated for each fatality to help prevent future incidents of a similar nature.

Between 1982 and the present, more than 1500 fatality investigations have been conducted and reports distributed. These reports are available on the NIOSH FACE web page. ${ }^{4}$ In addition to individual investigation reports, information gained from clusters of similar fatal incidents has been published in topic specific areas such as skylights, scaffolds, logging, skid-steer loaders, and forklifts. ${ }^{5-9}$ Some are available in Spanish, French, and Chinese. Three monographs-Worker Deaths in Confined Spaces, ${ }^{10}$ Worker Deaths from Electrocution, ${ }^{11}$ and Worker Deaths from Falls ${ }^{12}$ - detail findings and prevention recommendations from surveillance data and more than 400 FACE investigations. Additionally, numerous articles have been published in scientific and trade journals, ${ }^{13-29}$ and national and international presentations have been given using FACE data.

The value of FACE research in prevention efforts is illustrated in the following case examples. They range from targeted dissemination of prevention measures and improved state regulations to partnerships between government and industry to reduce worker deaths. 


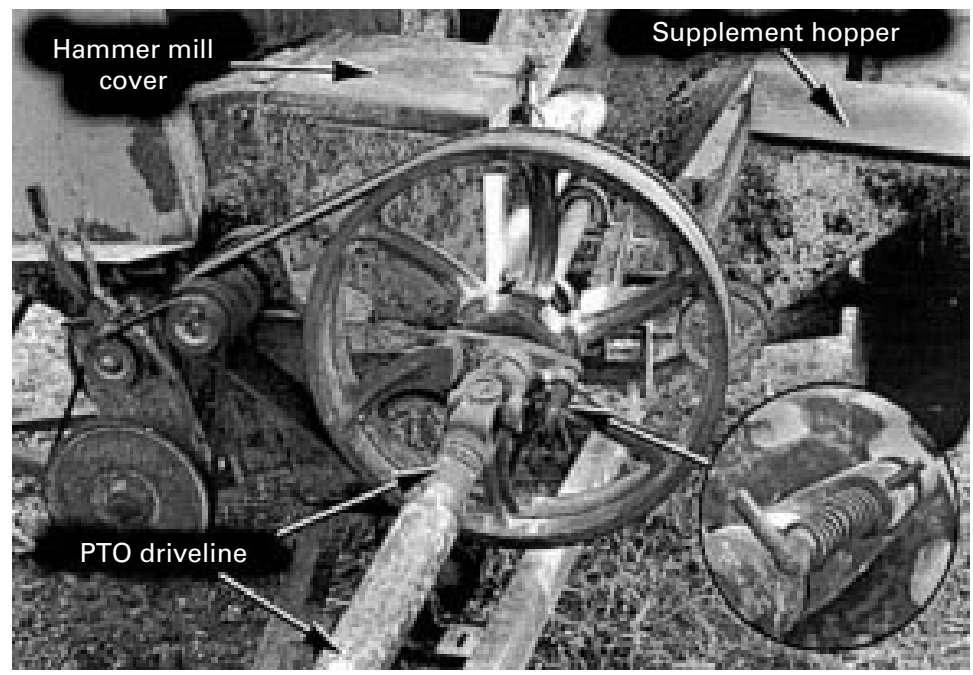

Figure 2 Power take-off (PTO) responsible for death of farm youth when jacket was caught in the unguarded clutch drive pin of a feed grinder-mixer (Iowa, 1999). The photo insert provides a close up view of the exposed clutch drive pin which rotated with the PTO shaft. opposite side of the PTO driveline near the location of the hammer mill cover (see fig 2). The PTO was rotating at approximately 200 rotations per minute. Suddenly the farmer heard a thump and saw the youth become instantly entangled around the driveline near the flywheel clutch. The youth died instantly. The coroner's official cause of death was decapitation. Examination of the flywheel after the incident revealed that the youth's jacket had caught on the unguarded clutch drive pin which lead to the entanglement.

Iowa FACE released their report to the employer in March 1999 and disseminated it throughout the state by publishing it in a farming magazine whose readership included thousands of Iowa farmers. ${ }^{31}$ The report summarized the investigative findings and offered recommendations to help employers prevent similar incidents. The recommendations included not using machines with damaged components until all repairs are completed and the system is working properly; completely shielding PTO drivelines and other drive-train components to prevent worker contact with rotating machine parts; training workers to recognize the hazards of working near exposed PTO drivelines and other rotating machine parts; and adequately illuminating all work areas. old male farm helper that occurred on a dairy farm in northern Iowa. ${ }^{30}$ Investigators from the Iowa FACE program contacted the employer and visited the site two days after the incident. They learned that the victim had worked on the farm on a part time basis for approximately six months before the fatal incident and had no previous experience in farm work. He had never lived on a farm. The farmer who employed him had no formal safety program, which is typical of most farm operators in Iowa, but had provided specific hazard instructions related to farming tasks.

On the day of the fatal injury, the farmer and the youth were mixing feed using a tractor power take-off (PTO) driven grinder-mixer to mix soybean protein supplement with ground corn. The grinder-mixer had two systems, grinding (milling) and mixing. The PTO shaft had a clutch mechanism which engaged the flywheel and the milling mechanism. For mixing, the flywheel was disengaged and remained stationary (floated) while the PTO shaft turned inside the flywheel hub. The clutch for the flywheel included exposed spring loaded drive pins, which rotated with the shaft. Shields for the driveline and the flywheel had been damaged and removed by the farmer 10 years earlier.

Just before the incident, the youth and the farmer were working together pouring feed supplement directly into the hammer mill opening. Normally a special hopper would have been used for this purpose but the hopper had never worked properly and was no longer used. After they finished pouring the supplement directly into the hammer mill opening, the farmer closed the hammer mill cover. The youth was standing next to the rotating PTO driveline on the hopper side of the grindermixer. The farmer was standing on the

\section{Findings and recommendations used in legislative efforts}

On 22 June 1994, the New Jersey FACE program learned through a newspaper article trocuted after contacting a faulty water pump motor in the pump room at a public swimming pool. Investigators from the New Jersey FACE program contacted the employer and conducted an on-site investigation. Investigators interviewed the employer, photographed the scene, and reviewed OSHA, police department, and medical examiner reports.

New Jersey FACE investigators determined that the following series of events had taken place on the day of the incident. The lifeguard checked in for work at $6 \mathrm{pm}$ when the pool was closed. He took a brief swim and then entered the pump room to begin his maintenance duties, one of which was to adjust the chlorine flow to the pool. As he reached across several pipes to the chlorine flow controls mounted on the wall, his leg contacted the metal housing of the pool pump, which had been energized to 220 volts due to an electrical fault in the pump motor. (See fig 3 for layout of the pool pump of the incident.) Nearby residents heard the lifeguard cry out for help and found him unconscious on the pump room floor, his leg still under the motor. The residents called the police who disconnected the power before attending to the victim. Emergency medical service providers administered cardiopulmonary resuscitation at the scene before taking the victim by ambulance to a local emergency room where he was pronounced dead from electrocution. that a 20 year old male lifeguard had been elecroom and the location of the victim at the time 


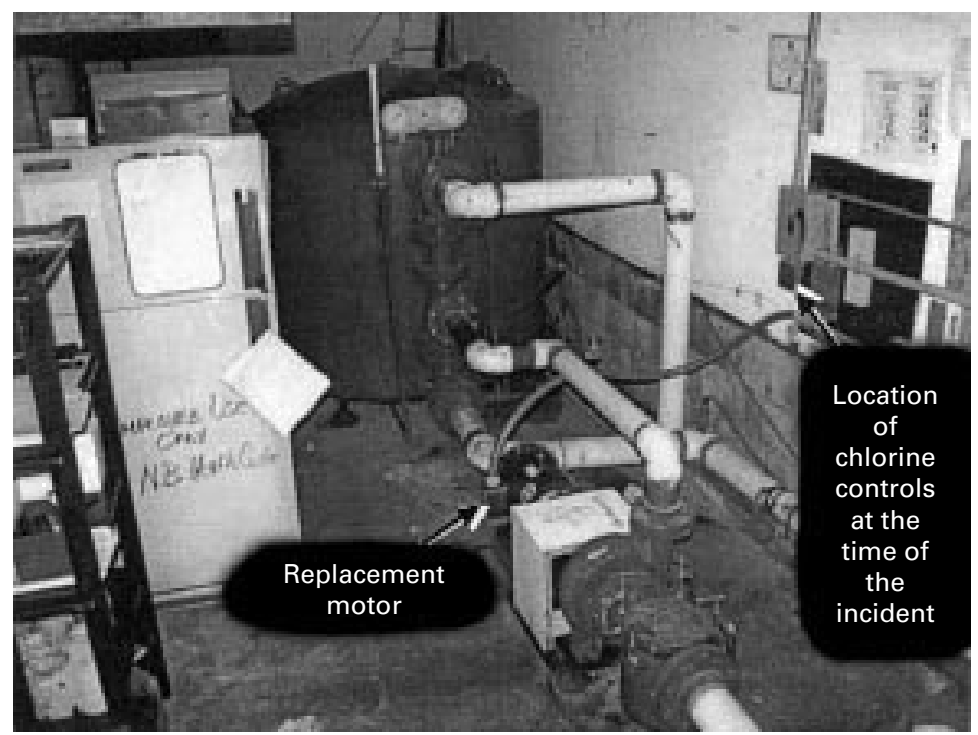

Figure 3 Swimming pool pump room. Site of electrocution due to faulty electrical pump motor (New fersey, 1994). The faulty equipment has been replaced.

During the course of the federal OSHA fatality investigation, which was completed the day after the fatal incident and before the New Jersey FACE investigation, an electrical inspector examined the junction box on the pump motor and found that some loose wires had contacted the inside of the box, electrifying the pump's metal housing. The 20 year old pump was not approved for use in wet locations by the manufacturer and had not been inspected for at least 10 years. There were no township, city, or state requirements for such inspections at the time of the incident. There were worker safety regulations enforceable by OSHA that applied to hazards found at the pool, but OSHA does not routinely inspect swimming pools as they are not part of a high risk industry. As a result of the OSHA fatality investigation, the employer received 14 serious OSHA violations, five of which were related to electrical problems found in the pump motor wiring.

New Jersey FACE released their report to the employer in February 1995 and disseminated it to government agencies, safety organizations, universities, and private employers throughout the state..$^{32}$ The report summarized the investigative findings and offered recommendations to help employers prevent future incidents. The recommendations included inspecting pool equipment and maintaining it in safe operating condition, locating electrical controls where they could be safely operated, and training employees to recognize potential electrical hazards. Additionally, investigators recommended that state agencies require that all swimming pools receive periodic electrical inspections and that electrical systems at swimming pools be fitted with ground fault circuit interrupters.

Recognizing that similar conditions might exist at other public pools throughout the state, New Jersey FACE published a hazard alert bulletin entitled Warning-Electrocution Hazard for Employees at Public Swimming Pools, and released it before the start of the 1995 swimming season. ${ }^{33}$ The bulletin briefly explained the incident and repeated the major recommendations from the investigative report. New Jersey FACE sent 3200 bulletins to local health departments in New Jersey for distribution during their biannual swimming pool health inspections. Five hundred fifty bulletins were also mailed to summer youth camps with their license applications. The bulletins were redistributed again the following year.

After sending out the hazard alert bulletin, New Jersey FACE mailed a follow up survey to 270 randomly selected pools and youth camps asking whether their swimming pools had been inspected and, if so, if electrical problems were present. Seventy three per cent of the respondents who received the hazard alert bulletin indicated they had their swimming pools inspected. Thirty seven per cent of those who had inspected their pools reported finding electrical problems.

In response to the electrocution of the lifeguard, the municipality of Old Bridge, New Jersey, passed an ordinance in October 1994 requiring periodic inspection of swimming pools to help prevent electrocutions. The ordinance, drafted by the New Jersey Municipal and Electrical Inspectors Association, required owners of public swimming pools in the township to obtain an electrical bonding and grounding certification. Pool owners were to hire a company to conduct the testing from a list of companies approved by the township. Pool owners were also required to obtain a permit from the Code Enforcement Department of the township and hire an inspector to conduct an annual inspection of the pool's wiring system. During 1995, the first year of ordinance implementation, 15 of the town's 21 pools $(71 \%)$ failed their initial inspection because they did not meet one or both of the electrical requirements.

The New Jersey Municipal and Electrical Inspectors Association sought the help of state legislators who proposed a state law establishing basic electrical standards for public swimming pools. In February 1996, members of the New Jersey State Assembly and Senate introduced bills modeled on the Old Bridge swimming pool ordinance. The New Jersey FACE hazard alert bulletin was cited in the bill's narrative to justify the new law. After several years of discussion and modification, New Jersey Pool Law, P L1998 c137 was signed into law by Governor Whitman on 14 December 1999. ${ }^{34}$ The law applies to all public swimming pools, hot tubs, or spas on any property other than one or two family residential properties. The law requires the pool owner to obtain a bonding and grounding certificate and an electrical certificate of compliance before opening the pool. The bonding and grounding certificate is issued after an inspection by a licensed electrician. It verifies the integrity of the bonding and grounding system and is good for five years. In addition, the law requires pool owners to obtain an electrical certificate of compliance that verifies that all wiring in the pool pump room is in compliance with the electrical subcode of the State Uniform Construction 
Code. This certificate must be renewed annually and is obtained from the state enforcement agency following an inspection conducted by the enforcement agency. The electrical certificate of compliance is issued annually after the inspection to verify that the equipment meets state electrical codes. As of January 2001, the New Jersey FACE program has not identified any additional work related electrocutions at New Jersey public swimming pools.

\section{Findings and recommendations used in a partnership effort to reduce worker deaths}

The widespread use of wireless communications services has fueled the construction of towers that hold transmitting devices for cellular phones, personal communication services, and broadcast antennas for television and radio. The Telecommunications Act of 1996 fueled an increase in tower construction to meet the increased demand for wireless communication services. Investor's Business Daily estimates that, by the year 2010, 100000 additional towers will be needed to accommodate digital phone services alone. ${ }^{35}$ Gross estimates of telecommunication tower construction projected for the next decade are shown in fig 4 .

Based on an analysis of narrative data from CFOI, a minimum of 118 workers died during the construction or maintenance of telecommunication towers in the United States during the seven year period 1992-98 (unpublished data, NIOSH, 2000). Falls from towers, followed by tower collapse, accounted for the majority of these deaths.

In 1997, OSHA established a multiagency Tower Task Force, which was comprised of representatives from various agencies including federal OSHA, NIOSH, the Federal Aviation Administration, the United States Army Corps of Engineers, and the United States Navy. The Tower Task Force worked with the National Association of Tower Erectors to address hazards associated with tower construction and to provide OSHA compliance officers with guidelines to follow during tower construction inspections. As a result of task force efforts, OSHA issued compliance directive CPL 2-1.29 Interim Inspection Procedures During Communication Tower Construction Activities, effective 19 January $1999 .{ }^{36}$ The directive outlines procedures to be followed during tower construction and requirements for

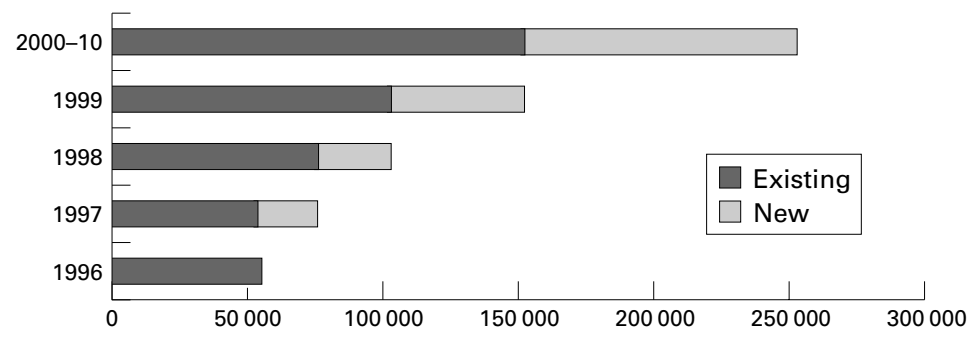

Figure 4 Projected Telecommunication Tower Construction. Sources: Federal Communications Commission, National Association of Tower Erectors, Investor's Business Daily. worker training, personal protective equipment, hoisting of employees, communication between workers on towers and workers on the ground, hydraulic hoists to be used to lift personnel and for the use of $100 \%$ fall protection when working at heights greater than 25 feet. The task force also addressed a second major safety concern, the use of gin poles in tower construction. A gin pole is a temporary lifting device unique to the telecommunications industry used to lift successive sections of tower steel, equipment, or workers into position. OSHA is currently drafting a compliance directive which will address the use of gin poles in tower construction and will require, at a minimum, a registered engineer's drawing at the site showing the gin pole, its manner of attachment to the tower, and its lifting capacity.

$\mathrm{NIOSH}$ and Missouri FACE personnel have investigated 10 tower related fatal fall incidents. ${ }^{37-46}$ These fatality investigations suggest that employers, supervisors, workers, tower owners, tower manufacturers, and wireless service carriers may not fully appreciate the serious fall hazards associated with tower construction and maintenance and therefore may not follow adequate safe work procedures for controlling these hazards. To help prevent falls from towers, FACE investigators recommended that employers develop, implement, and enforce a written comprehensive safety program, specific to tower construction and maintenance. Additionally, NIOSH recommends that employers ensure that workers adhere to OSHA compliance directives pertaining to tower erection, provide workers with required fall protection and training in its proper use, and instruct workers in proper tower climbing techniques. Employers should also ensure that gin poles are installed and used according to manufacturers' or professional engineers' specifications and ensure that hoisting equipment used to lift personnel is designed to prevent uncontrolled descent and is properly rated for its intended use. Employers should also know and comply with child labor laws that prohibit hazardous work by young people under 18, including work in any occupations involved in the operation of power driven hoisting equipment.

$\mathrm{NIOSH}$ investigators also recommended that tower manufacturers and owners consider installing fall protection fixtures into tower components during tower fabrication and erection. Tower owners should ensure that contractors performing work on their towers have a safety and health program specific to tower construction and maintenance and include in the contract a provision for frequent and regular inspection of the jobsite. These inspections should be performed by a competent person who has expertise in tower erection and worker fall protection.

Utilizing information gained through investigations and the collaborative efforts of the task force, the National Association of Tower Erectors' safety and health manual has been revised, and tower safety information has been disseminated through publications in trade magazines and at training seminars and national and 
international conferences. A NIOSH document entitled Preventing Fall-Related Deaths and Injuries of Workers Involved in Telecommunication Tower Construction and Maintenance will be published in 2001. NIOSH, OSHA, and the National Association of Tower Erectors will continue to work together to help prevent injuries and deaths of workers who construct or maintain telecommunication towers.

\section{Discussion}

According to CFOI, about 17 workers were fatally injured at work each day in the United States in 1999. Both the rate and the numbers of occupational fatalities in the United States are decreasing, but with 6023 deaths in 1999, more needs to be done. Programs such as FACE demonstrate one approach for prevention of traumatic occupational fatalities. NIOSH believes that all occupational fatalities are preventable and is committed to collaborating with other federal and state agencies as well as with employers, workers, organizations that represent employers and workers, equipment manufacturers, safety and health professionals, parents, and other individuals and groups who can intervene in the workplace to help prevent and reduce traumatic occupational fatalities.

To learn more about the FACE program, please contact NIOSH, Division of Safety Research, Surveillance and Investigation Branch, at 304-285-5916. Copies of NIOSH documents are available from the NIOSH Education and Information Division at 1 (800) 356-4674 or can be obtained by visiting the Division at 1 ( 800$) 356-4674$ or can be obtained by visiting the
NIOSH web site at http://www.cdc.gov/niosh. The NIOSH FACE reports can be obtained more directly by using the FACE web site at http://www.cdc.gov/niosh/face/faceweb.html.

1 National Institute for Occupational Safety and Health. Fatal injuries to civilian workers in the United States, 1980-1995. $\mathrm{OH}$ : US Department of Health and Human Services, Public Health Service, Centers for Disease Control and Prevention, National Institute for Occupational Safety and Health, DHHS (NIOSH) No 2001-29 (in press).

2 Bureau of Labor Statistics. Census of fatal occupational injuries summary. Washington, DC: US Department of Labor, Bureau of Labor Statistics, USDL 00-236, 17 August 2000.

3 Haddon WH. The changing approach to the epidemiology, prevention, and amelioration of trauma: the transition to prevention, and amelioration of trauma: the transition to
approaches etiologically rather than descriptively-based. Amproaches etiologically rather than

4 Information available on the world wide web at www.cdc.gov/niosh/face/faceweb.html. Accessed $21 \mathrm{Febru}-$ ary 2001

5 National Institute for Occupational Safety and Health. NIOSH alert: request for assistance in preventing worker death and injuries from falls through skylights and roof openings.

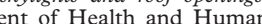
Services, Public Health Service, Centers for Disease Control and Prevention, National Institute for Occupational Safety and Health, DHHS (NIOSH). Publication No 90-100, 1989.

6 National Institute for Occupational Safety and Health. NIOSH alert: request for assistance in preventing worker injuries and deaths caused by falls from suspension scaffolds. Cincinnati, OH: US Department of Health and Human Services, Public Health Service, Centers for Disease Control and Prevention, National Institute for Occupational trol and Prevention, National Institute for Occupational Safety and Hea

7 National Institute for Occupational Safety and Health. NIOSH alert: request for assistance in preventing injuries and deaths of loggers. Cincinnati, OH: US Department of Health and Human Services, Public Health Service, Centers for Disease Control and Prevention, National Institute for Occupational Safety and Health, DHHS (NIOSH). Publication No $95-101,1994$

8 National Institute for Occupational Safety and Health. NIOSH alert: preventing injuries and deaths from skid-steer loaders. Cincinnati, OH: US Department of Health and Human Services, Public Health Service, Centers for Disease Control and Prevention, National Institute for Occupational Safety and Health, DHHS (NIOSH). Publication No 98-117, 1998 .

9 National Institute for Occupational Safety and Health NIOSH alert: preventing injuries and deaths of workers who operate or work near forklifts. Cincinnati, OH: US Department of Health and Human Services, Public Health Service, Centers for Disease Control and Prevention, National Institute for Occupational Safety and Health, DHHS (NIOSH). Publication No 2000-112, 2000

10 National Institute for Occupational Safety and Health. Worker deaths in confined spaces. OH: US Department of Health and Human Services, Public Health Service, Centers for Disease Control and Prevention, National Institute for Occupational Safety and Health, DHHS (NIOSH). Publication No 94-103, 1994.

11 National Institute for Occupational Safety and Health. Worker deaths from electrocution. OH: US Department of Health and Human Services, Public Health Service, Centers for Disease Control and Prevention, National Institute for Occupational Safety and Health, DHHS (NIOSH). Publication No 98-131, 1998.

12 National Institute for Occupational Safety and Health. Worker deaths from falls. OH: US Department of Health and Human Services, Public Health Service, Centers for Disease Control and Prevention, National Institute for Occupational Safety and Health, DHHS (NIOSH). Publication No 2000-16, 2000 .

13 Braddee RW, Pettit TA. Warning: confined space-signs help to spread the safety message. Operations Forum 1986; 3:22-3.

14 Etherton JR, Myers JR, Jensen, et al. Agricultural machinerelated deaths. Am $\mathcal{F}$ Public Health 1991;81:766-8.

15 Hanrahan LP, Higgins D, Haskins L, et al. Project FACE: Wisconsin surveillance of fatal occupational injuries. Wis Med f 1992;91:43-5.

16 Helmkamp J, Kennedy R, Fosbroke D. Occupational fatalities in the fishing, logging, air transportation industries in Alaska-1991. Scand $\mathcal{F}$ Work Environ Health 1992;18(suppl 2):55-7.

17 Centers for Disease Control. Electrocutions in the construction industry involving portable metal ladders-US, 19841988. MMWR Morb Mortal Wkly Rep 1992;41(11):187-9.

18 Bledsoe G. Confined spaces: potential hazards for emergency rescue personnel. Response EMS Alaska Fall 1993: 10

19 Centers for Disease Control and Prevention. Fatalities attributed to entering manure waste pits-Minnesota, 1992. MMWR Morb Mortal Wkly Rep 1993;42(17):325-9.

20 Suruda A, Fosbroke DE, Braddee RW. Fatal work-related falls from roofs. Safety Res 1995;26:1-7.

21 Harrison R, Gillen M. Surveillance and investigations of homicides at work: California Fatality Assessment and Control Evaluation program. Occup Med 1996;11:243-5.

22 Centers for Disease Control and Prevention. Skid-steer loader-related fatalities in the workplace-United States, 624-8.

23 Braddee RW, Myers JR. Logging-type fatalities in the US production agriculture industry, 1980-1992. Agromedicine 1997;4(3/4):373-5.

24 Braddee RW, Pratt SG, Hause M. Preventing falls from elevations. American Welding 1997,Spring:23-5.

5 Brown M, Parker, D, Seeland, E, et al. Five years of work-related injuries and fatalities in Minnesota. Minn Med 1997;80:29-31.

26 Pratt SG, Hard DL. Injury factors associated with agricultural workplace fatalities. Agric Saf Health 1997; Special issue No 1:29-38.

27 Etre L, Johnson WE. Arc welder dies in explosion. The World of Welding 2000;Summer:8-10.

28 Helmkamp JC, Lundstrom WJ. Work-related deaths in West Virginia from July 1996 through June 1999: surveillance, investigation, and prevention. Am College Occup Environ investigation, and pre

29 Struttmann TW, Scheerer AL. Fatal injuries caused by logs rolling off trucks: Kentucky 1994-1998. Am F Ind Med 2001;39:203-8.

30 Iowa Department of Public Health. Youth farm worker is killed when he becomes entangled in PTO driveline of an old grinder-mixer. IA: Iowa Department of Public Health, University of Iowa, Department of Preventive Medicine and Environmental Health, IA Fatality Assessment and Control Evaluation (IAFACE). Report No 99IA003, 1999.

31 Johnson WE, Rautianen R. Beware of the driveline. Wallaces Farmer Magazine 2000;March:88-90.

32 New Jersey Department of Health and Senior Services. Lifeguard electrocuted after contacting an energized pump motor housing. NJ: New Jersey Department of Health and Senior housing. NJ: New Jersey Department of Health and Senior Services, New Jersey Fatality Assessment and Co
Evaluation (NJFACE). Report No 94NJ09001, 1995.

33 New Jersey Department of Health and Senior Services. Warning-electrocution hazard for employees at public swimming pools. NJ: New Jersey Department of Health and Senior Services, New Jersey Fatality Assessment and Control Evaluation (NJFACE). Report No G4580, 1995.

34 Senate and General Assembly of the State of New Jersey. Pool Law, P L 1998 c137 [NJS 52:27D-119et seq], 1999.

35 OSHA. Profile of the wireless telecommunications industry and the telecommunications tower industry. Washington, Jack Faucett Associates, 1998.

36 36. Occupational Safety and Health Administration. CPL $2-1.29$ Interim inspection procedures during communica-
tion tower construction activities. Washington, DC: US Department of Labor, 1999.

37 National Institute for Occupational Safety and Health. Painter dies after 80-foot fall from electrical transmission tower-Indiana. WV: US Department of Health and 
Human Services, Public Health Service, Centers for Disease Control and Prevention, NIOSH, Division of Safety Research, Fatality Assessment and Control Evaluation (FACE). Report No FACE92-05, 1992.

38 National Institute for Occupational Safety and Health. Tower erector/inspector dies after falling 200 feet from a telecommunication tower to the ground-North Carolina. WV: US Department of Health and Human Services, Public Health Service, Centers for Disease Control and Prevention, NIOSH, Division of Safety Research, Fatality Assessment and Control Evaluation (FACE). Report No FACE97-10, 1997.

39 National Institute for Occupational Safety and Health. Tower worker dies after falling 130 feet from hoist cable to ground-Pennsylvania WV: US Department of Health and Human Services, Public Health Service, Centers for Disease Control and Prevention, NIOSH, Division of Safety Research, Fatality Assessment and Control Evaluation (FACE). Report No FACE98-05, 1998.

40 Nonional Intitute for Occupational Safety and Health. Tower erector dies after falling 125 feet from cellular phone
tower-South Carolina. WV: US Department of Health and Human Services, Public Health Service, Centers for Human Services, Public Health Service, Centers for
Disease Control and Prevention, NIOSH, Division of Safety Research, Fatality Assessment and Control EvaluaSafety Research, Fatality Assessment and Co
tion (FACE). Report No FACE98-07, 1998.

41 National Institute for Occupational Safety and Health. Tower erector dies after falling 200 feet from telecommunication tower-North Carolina. WV: US Department of Health and Human Services, Public Health Service, Centers for Disease Control and Prevention, NIOSH, Division of Safety Research, Fatality Assessment and Control Evaluation (FACE). Report No FACE98-20, 1998.
42 National Institute for Occupational Safety and Health. Tower painter dies and a second painter injured after falling 900 feet while inside a man basket - South Carolina. WV: US Service, Centers for Disease Control and Prevention, NIOSH, Division of Safety Research, Fatality Assessment and Control Evaluation (FACE). Report No FACE98-21, 1998.

43 National Institute for Occupational Safety and Health. Tower hand dies after 230-foot fall from communication towerNorth Carolina. WV: US Department of Health and Human Services, Public Health Service, Centers for Disease Control and Prevention, NIOSH, Division of Disease Control and Prevention, NIOSH, Division of tion (FACE). Report No FACE99-01, 1999.

44 National Institute for Occupational Safety and Health. Three tower painters die after falling 1,200 feet when riding the hoist line-North Carolina. WV: US Department of Health and Human Services, Public Health Service, Centers for Disease Control and Prevention, NIOSH, Division of Safety Research, Fatality Assessment and Control Evaluation (FACE). Report No FACE2000-07, 2000.

45 Missouri Department of Health. Tower construction worker dies following 940-foot fall from television tower. MO: Missouri Department of Health, Missouri Fatality Assessment and Control Evaluation (MO FACE). Report No 98MO161, 1999.

46 Missouri Department of Health. Tower construction worker dies following 200 foot fall from radio tower. MO: Missouri Department of Health, Missouri Fatality Assessment and Control Evaluation (MO FACE). Report No 98MO102, 1999. 